\title{
Discovery of the Rare Gas Helium Vindhyan Rocks, Southern Ganga Basin, Bundelkhand Region, Dist. Sagar, M.P. India
}

\section{Shandilya $\mathrm{AK}^{1 *}$, Anurag Shandilya ${ }^{1}$, Anupam Shandilya ${ }^{1}$ and Tiwari $\mathrm{RP}^{2}$}

${ }^{1}$ Department of Applied Geology, Dr. Hari Singh Gour University, India

${ }^{2}$ Vice Chancellor, Dr. Hari Singh Gour University, India

*Corresponding author: Arun K Shandilya, Department of Applied Geology, Dr. Hari

\section{Research Article}

Volume 3 Issue 4

Received Date: July 01, 2019

Published Date: August 28, 2019

DOI: $10.23880 /$ ppej- 16000200

Singh Gour University, Sagar, Madhya Pradesh, India, Tel: 09977576665; Email: akshandilya_u@rediffmail.com

\section{Abstract}

The studies on the helium in hydrocarbon rich petroliferous tube wells in Saugor Division, southern Ganga Basin region has been carried out in great detail in 50 Tube wells, along with the stable isotopic analysis were carried out for the gas sample were collected from the 50 tube wells in Sagar and Damoh District of M.P. The discovery of the rare gas helium in hydrocarbon rich zone in the tube wells in agricultural fields in Sagar District and in Damoh District of M.P. is a unique finding in rocks of the Vindhyan Super Group, in the history of Earth Science in India. The depth of tube wells are varying in 300 feet to 750 feet. On the basis of geochemical analysis, it is remarkable to note that average values of helium contents varies from $0.34 \%$ to $0.732 \%$ along with the $72 \%$ to $99 \%$ of methane and ethane, and minor amount of oxygen, nitrogen and $\mathrm{CO} 2$ gases in the hydrocarbon rich zone are recorded during the geochemical and stable isotope analysis. It has been found in the stable isotope $\delta \mathrm{C}^{13}$ value the values for the methane is - 43.6 per mil w. r. t. to - 54.9 per mil w.r.t. PDB and for the Ethane gas is --24.9 to --26.4 per mil w. r. t. PDB in the gas samples collected in the saturated sodium chloride solution in the glass bottles at various sites in Sagar \& Damoh District. The occurrence of rare helium gas in the Hydrocarbon rich zone is reported first time in Jan, 2007 from the tube wells of Sagar Distt, which were geochemically and stable isotopically analyzed in the labs of KDMIPE Dehradun \& NGRI Hyderabad. The gaseous hydrocarbon analysis show the presence of moderate to low concentration of methane ( C1) 1 to 104 ppb, Ethane( C2)-1 to $14 \mathrm{ppb}$, Propane( C3) 1 to $10 \mathrm{ppb}$, i- Butane ( i C4) 1 to $9 \mathrm{ppb}$ and n Butane ( n C4) 1 to 8 ppb in the soil samples collected from different locations. The result of stable isotopic analysis of Ethane gas in these samples $\delta \mathrm{C}^{13}$ value are ranging from -24.9 per mill w.r.t. PDB and -26.9 per mill w.r.t. PDB are indicative that this gas is of thermogenic origin, which must have been formed at very high temperature \& pressure condition in the deeper horizon of the Great Vindhyan sedimentary basin of an early Proterozoic ( $>600$ m.y.) period.

Keywords: Petroliferous; Tube wells; Hydrocarbon gas; Helium gas; Proterozoic; Isotopic; Thermogenic 


\section{Petroleum \& Petrochemical Engineering Journal}

\section{Introduction}

The present studies on the hydrocarbon gas anomalies in the seepages and leakages of natural petroleum rare gas Helium gases in the agricultural field of Sagar and Damoh district has been done in the hydrocarbon rich zone. These hydrocarbon gases and helium gas were escape from the reservoir and migrated to the surface, the secondary porosity in the rocks, sediment and soil or diffuse into the atmosphere or added in the ground water. These leakages of natural gas is an indication of petroleum gas in the form of oil and gas seeps from precursor underground. provides the direct evidence for the presence of petroleum accumulation underground. The samples of soil, water and gas were collected from the tube wells of agricultural field are located in the agricultural field of various villages in the Meerkheri, Rahatgarh (tahsil) Pipariya -Bhutoli villages in Garhakota tehsils of Sagar and Mahalwara village in Sukha block of patharia tahsil of Damoh distt. in the southern fringes of Bundelkhand region in M.P. The first time leakage of petroleum gas was reported in 1980 from the Meerkheri village located on the Sagar to Vidisha road, at about $15 \mathrm{~km}$ from the Rahatgarh town. In 1993, in another tube well at Rahatgarh the leakages were reported by the author.

The attempt has been made through the cheaper and faster method of geochemical prospecting, which

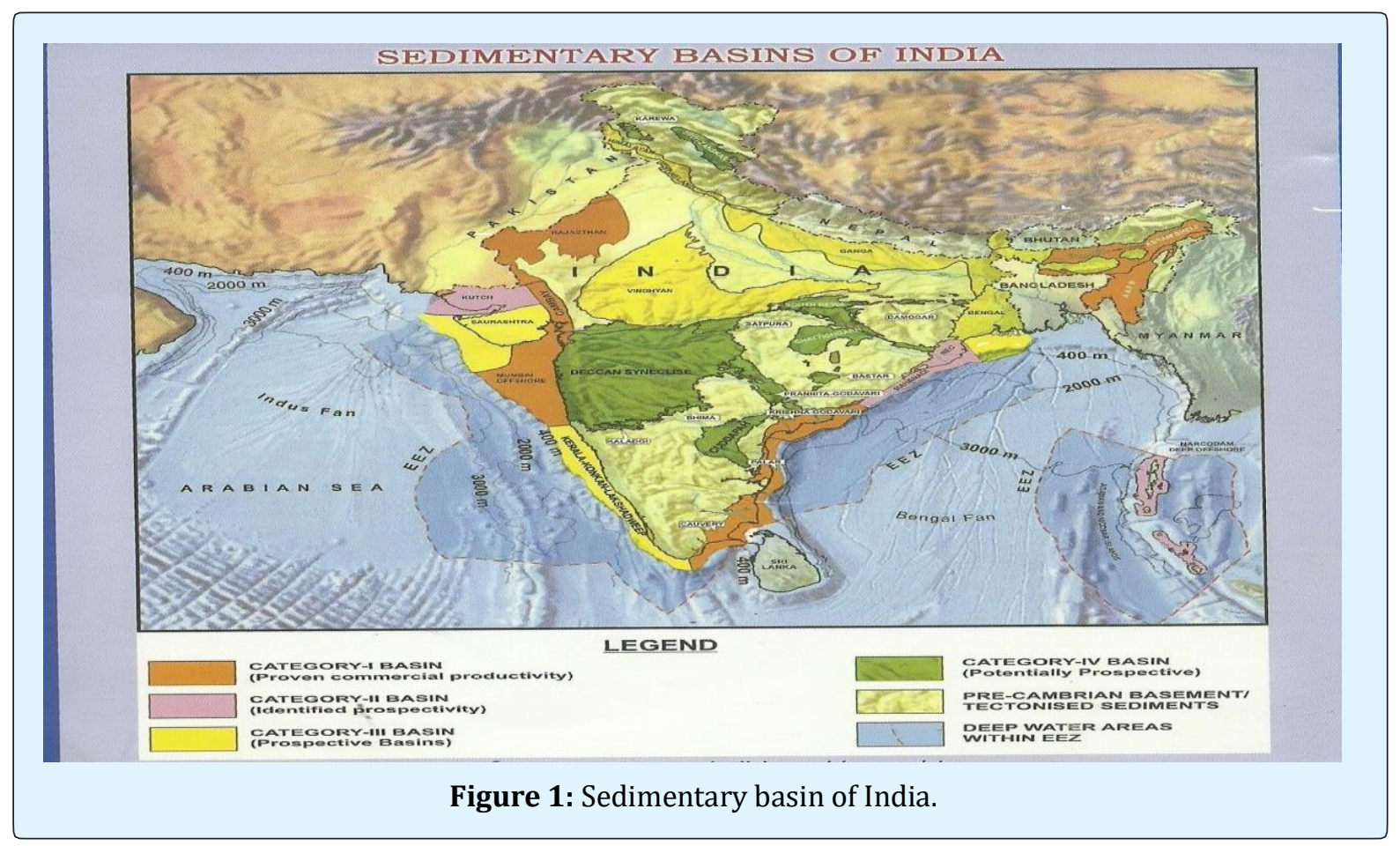

The carbon isotope studies of methane and other gases were done to know whether these petroleum gases are of biogenic of thermogenic origin. Coleman, et al. [1] in a study on the leakage of gas from the underground storage reservoir showed that isotopic analysis is a reliable technique for differentiating between methane from thermogenic and biogenic source. A useful geochemical method to correlate gases with their source rocks is $\delta \mathrm{C}^{13}$ determination. The isotopic composition of methane was found to be a more reliable indicator of hydrocarbon reservoir. Shandilya [2] has reported the occurrence of the petroleum gas in the Sagar District and suggested that theses petroleum gas is of thermogenic in origin.

Shandilya [3-6] made Discovery of Natural Gas leakages from Bore wells in the rocks of the Vindhyan Super group in Sagar and Damoh Distt. M.P. and forecasted the reserve of Natural Gas Reserves in Sagar District. Shandilya [7-9] published an article on GAS IN 


\section{Petroleum \& Petrochemical Engineering Journal}

THE BACKYARD. In the BUSINESS INDIA MAGZINE suggesting that this gas is of thermogenic origin. Shandilya [7-9] has suggested the possibility of Petroleum Gas reserve in Southern Bundelkhand Region. M.P. Shandilya \& Gajbhiye [10] made the Discovery of Rare Helium Gas in Sagar District, M.P. Prasanna, et al. [11] were done the detail investigation of light gaseous hydrocarbon anomalies in the surface soil around Sagar using the geochemical exploration methods for hydrocarbon leakages has been focused on the detection of absorbed petroleum gases by gas chromatographic method, in Vindhyan basin using composition and ratio of the light hydrocarbons methane, ethane, propane, butane.

\section{Geology}

The present natural gas leakages has been discovered in the dried tube wells, located on the rocks of Sandstone, shale and limestone rocks of the Rewa and Bhander Group of the Vindhyan Super Group as the basement rocks. These petroliferous rocks are overlain by the Lameta bed (late Cretaceous) in the western part of the Pipariya and Bhutoli area in Garhakota tahsil. On the western part of present area is overlain by the rocks of Upper Cretaceous Deccan Trap Basaltic flows, which are intercalated with intertrappean limestone. The area were the leakages of petroleum gas has been discovered located on the alluvial soil cover. The Deccan Trap Basaltic rocks are exposed west of the Chinnoua village in Garhakota Tahsil. The dips of the sandstone and shales rocks are 10 - 15 degree toward SE direction. The topography is more or less flat with some low lying areas near the stream. The geological formation of Sagar area consists of 09 flows of Deccan Trap.

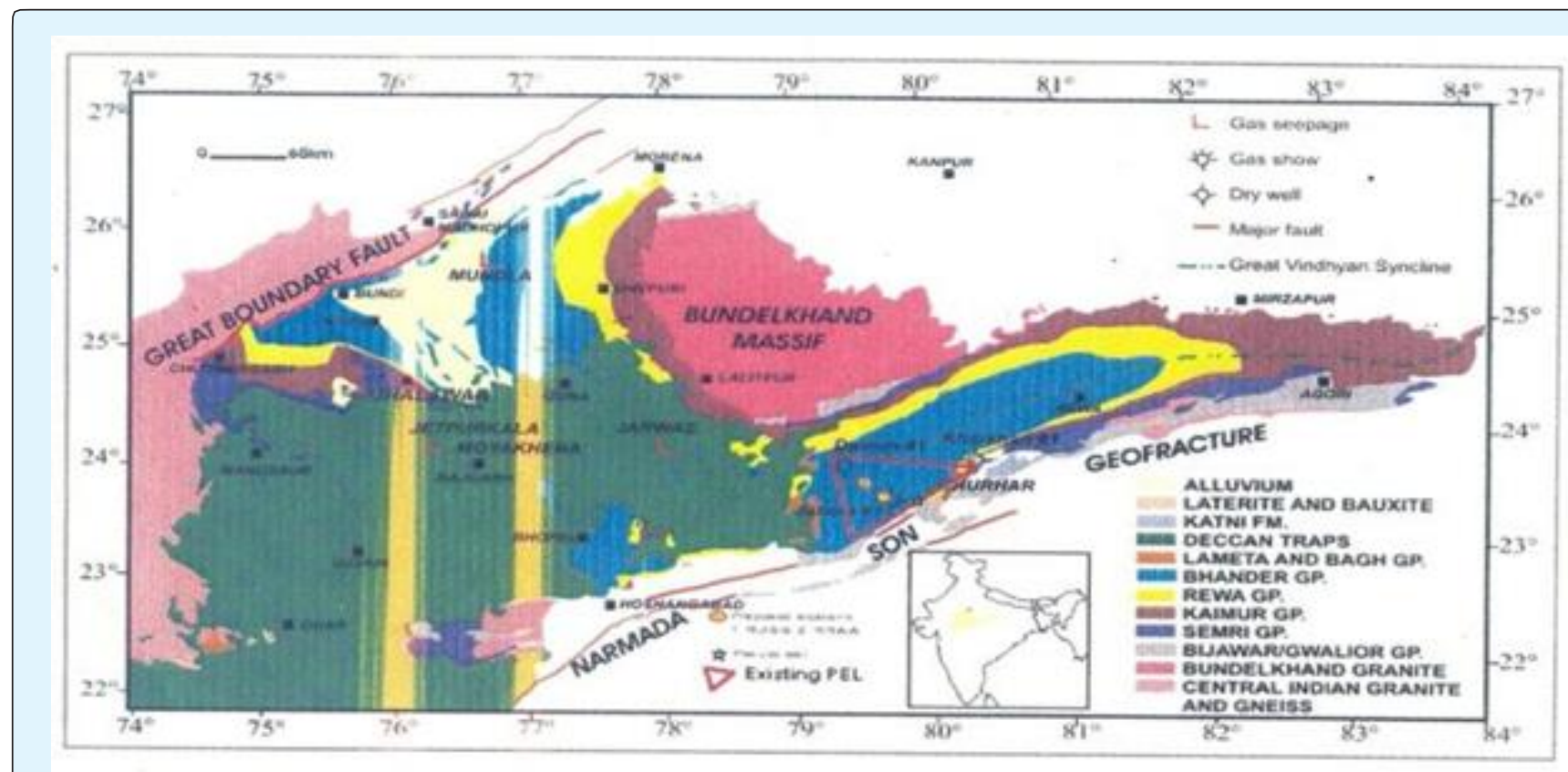

Figure 2: Geological map of Vindhyan Basin showing existing PEL, Surface gas seepages, Drilled wells, Pseudo-well and proposed locations.

With several intertrappean limestone beds, whole area being underlain to the east and south by the Lameta limestone. Which forms the plains and some hills to the south. Western fringe of The Rahatgarh and Meerkheri areas are covered mostly by the Basaltic flows of Deccan Traps except few inliers of the shale and sandstone rocks of Rewa Group and Bhander Group of the Vindhyan Super
Group. The Deccan Trap basalt rocks are mostly covered by the black soil. The Deccan volcanism during late Cretaceous must have generated the proper thermal conditions and acted as a catalyst in triggering Mesozoic hydrocarbon generation processes in the Vindhyan sedimentary basin in Central India. 


\section{Petroleum \& Petrochemical Engineering Journal}

\begin{tabular}{|c|c|}
\hline Lower Cretaceous & Lameta Formation \\
\hline \multirow{4}{*}{$\begin{array}{l}\text { Late Proterozoic Vindhyan } \\
\text { Super Group }\end{array}$} & Bhander (Containing the Petroleum gas \& Helium gas) \\
\hline & Rewa \\
\hline & Kaimur \\
\hline & Semri \\
\hline \multirow{11}{*}{$\begin{array}{l}\text { Middle Proterozoic } \\
\text { Bijawar Super Group }\end{array}$} & Phosphastic Dol- The Stratigraphic Succession in Sagar \\
\hline & Formation \\
\hline & Recent Sub Recent/Quaternaries \\
\hline & Deccan Trap Basalt ( with Intertrapean limestone) \\
\hline & \\
\hline & Dolomite \\
\hline & Ferrugenous Shale \\
\hline & Ferrugenous Sandstone \\
\hline & Iron Formation / BHQ \\
\hline & Quartzite \\
\hline & Conglomerate bed. \\
\hline \multirow{6}{*}{$\begin{array}{c}\text { Early Proterozoic } \\
\text { Bundelkhand Granite } \\
\text { Complex }\end{array}$} & Quartz reef intrussion \\
\hline & Pegmatitic intrussion \\
\hline & Ultramafic intrusive \\
\hline & Granite Intrussive rocks \\
\hline & Granite Gneiss \\
\hline & Biotite Schist \\
\hline \multirow{6}{*}{$\begin{array}{c}\text { Archean Mehroni Super } \\
\text { Group }\end{array}$} & Intrussive body \\
\hline & Dolomitic Marble \\
\hline & Slate \\
\hline & Ferrugenous Formation \\
\hline & Quartzite \\
\hline & Schist \\
\hline
\end{tabular}

Table 1: Description of Lower Cretaceous and Lameta Formation [12].

\section{Observation}

On the request of authors, the Director Exploration, KDM IPE, ONGC Dehradun and Director, NGRI Hyderabad has sent a team of scientists for the detailed investigation had visited the Piparia-Bhutoli and Rahatgarh and Meerkheri area and collected the samples of soil, water and gas. The samples were collected from the following localities-

\section{Bhu-1}

These tube wells fall under the panchayat and P.O. chanauaa tahsil Garhakota dist. Sagar, M.P.(part of survey of India top sheet no. 55M/1) It is accessible by a $3 \mathrm{~km}$ Village road from town Garhakota around $45 \mathrm{~km}$ East of Sagar on way to Damoh. The leakage of petroleum gas is reported from 08 tube wells in the month of march 2007.

1. These bore/tube wells varying in the depth from 260 to $400 \mathrm{ft}$, with top $60 \mathrm{ft}$ is of 8" diam with plastic casing, and rest of well is of 6" diam. depth 340 feet) of Shri
Bhagwan singh Yadav (lat: 23047'59.2"N, long 7905'29.6" E, Elevation 448m).

2. Pip-1 The tube wells (depth 400 feet) of Sri Asharam Patel S/o Sri Ghappu Patel (lat: 23048'20" N, long: 79०50'20.7" E, elevation 450m).

\section{Rah-1}

This village is located $40 \mathrm{~km}$ west of Sagar on way to Bhopal Road. In the bore well of Shri Leeladhar Tiwari (Tiwari Dhawa: lat: 23o57'15.7" N, Long: 79o25'03"E, Elevation $484 \mathrm{~m}$ ), the tube well is situated on the deccan trap - Vindhyan contact. The leakage of petroleum gas is reported since 1993.

\section{Mee-1}

This tube well (lat: 234' $56^{\prime \prime} \mathrm{N}$, Long:78०18'9.6"E, Elevation $440 \mathrm{~m}$ ) from where gas seepage was occurring belongs to Shri Dhan Singh. The area falls in the toposheet 


\section{Petroleum \& Petrochemical Engineering Journal}

of India No. 55 I/5. This tube well is the eastern extremity of village meerkhedi, $13 \mathrm{~km}$ of Rahatgarh on way to Vidisha. This tube well pouring the petroleum gas since 1984 having enormous bubbling in the water. The tube well is located on the contact of deccan tram basalt and vindhyan sand stone (Inlier).The quantity of petroleun gas bubbling ins increase day by day.

\section{Mah-1}

The leakages of the petroleum gas has been reported in 2009 from this village in Patharia Tahsil of Damoh district. The 378 feet deep tube well is pouring the water along with the natural petroleum gas and the water which is coming out of the tube well is burning upto 2-3 feet long flame. In the bore well of Sri Halle singh Lodhi at Mahalwara about $11 \mathrm{~km}$ north of Patharia railway Station in Damoh Distt. Is also containing the leakages of petroleum gas in the 378 deep tube well, which was digged in Nov. 2008. The tube well water getting fire, when light up the matchstick about $1.00 \mathrm{~m}$ high flame burning in water. The petroleum gas is also coming out of the tube well when no pumping is done, the leakage of the gas can be easily seen in it.

\section{Bat-1}

It is located about $25 \mathrm{Km}$ from Damoh. In the tube wells the water gives the smell of kerosene / diesel in the month of Nov.-Dec. 2008 onward. The tube wells are varying ibn depth from 350 to 400 feet in the Vindhyan Limestonerocks.

\section{Pat-1}

In this village the tube well is situated in the inliers of the Vindhyan Rocks among the Deccan Trap cover, the tube well was digged in 2000, and depth id about 380 feet. It is also pouring the natural petroleum gas as it was reported in Nov. 2011.

\section{SUK-1}

In the agricultural field near the Limestone quarry of Narsinghgarh Cement (Heidel berg Cement Plant) there is a leakages of petroleum gas along with water. Reported in Dec.2009

\section{Man1}

A tube well situated in the Deccan trap rocks in Mandi Bamora, depth is 390feet, digged in May2012 a; so pouring the natural gas along with water . The flame of 810 feet was observed at the well site in the Public Health
Centre at Mandi Bamora. The thickness of the Deccan trap in very low at the site, resting over the rocks of Vindhyan Super Group, in the northern most extend of the Deccan cover.

\section{Kon-1}

At this village the tube wells are also pouring the gas during the month of Nov. and Dec. and the water is giving the smell of the kerosene in it. It is situated on the rocks of the Vindhyan Super Group.

\section{Jhi-1}

The tube well is situated on the inlier of the Vindhayn rocks. The tube well was digged in Deccan trap rocks, which has overlying the rocks of Vindhyan Super Group. The depth of tube wells are varying from 300- 400 feet.

\section{Ban-1}

In this village the leakages of the natural petroleum gas has been reported in March 2012, from a tube wells which is about 360 feet deep. The gas with more speed in coming in the afternoon hour and with bubbling sound from the tube wells.

\section{Gho-1}

The Gho-1 falls in the Banda Tahsil of Sagar District. About $25 \mathrm{Km}$ from Banda, on way to Patharia. In this village there are six (06) tube wells pouring natural gas along with the water. Two hand pump are also leak aging this petroleum gas and burning day and night, with the help of the local administration the fire has been controlled on $7^{\text {th }}$ May 2012. The continuous gas leakage has been reported from this village. In the agriculture field of the villagers. The tube wells were digged in different time, but all of them are pouring the natural gas, which is burning 6-8 feet long flame. The experiment of the gas leakages were done in some of the old tube wells, in which the natural gas in coming along with water which buning, one can say that there is water in burning (Paani me Aag).

\section{Geochemical Analysis}

\section{At ONGC Dehradun}

The samples were analysed in the geochemical laboratory of KDM IPE Kaulagarh Road, ONGC, Dehradun. The finding of the geochemical analysis of the natural gas, water, and soil are as follows- 


\section{Petroleum \& Petrochemical Engineering Journal}

\begin{tabular}{|c|c|c|c|c|c|c|c|c|}
\hline \multirow{2}{*}{ S.No. } & \multirow{2}{*}{ Bore Well } & \multicolumn{6}{|c|}{ Chemical Composition \% (v/v) } & \multirow{2}{*}{$\begin{array}{c}\text { Isotopic Values ( } \delta \text { C13) } \\
\delta \text { C13 }\end{array}$} \\
\hline & & He & $\mathbf{O}_{2}$ & & $\mathrm{CO}_{2}$ & C1 & $\mathrm{C} 2+$ & \\
\hline 1 & Pipariya Bhatoli & 0.34 & 1.6 & 24.87 & 0.93 & 72.14 & 0.01 & -61.5 \\
\hline 2 & Rahatgarh & 0.72 & 0.65 & 14.37 & 0.28 & 84 & 0.02 & -54 \\
\hline
\end{tabular}

Table 2: Geochemical Composition of Natural Gas and stable Isotope values [2].

The Oil and Natural Gas Commission Dehradun has concluded with, The seepaged gases of Pipariya Bhatoli and Rahatgarh are predominantly methane (72.14\%-84 $\%$ in Pipariya Bhutoli and $99 \%$ in Tiwari Dhaba, Rahatgarh Bore well and are devoid of higher hydrocarbons. the hydrocarbon gases seem to have predominance of bacterial methane. The pressure of both the seepages is extremely low. As per the owners, the quantity of gas is diminishing day-by-day. The results this time of methane is concerned. Genetically the seepage gases from Pipariya Bhatoli and Rahatgarh seem to be different from thermogenic gases encountered in exploratory well jabera-1, drilled by ONGC in Distt. Damoh (M.P.).

In January 2008 in Bhutoli village further land owner bore the well up to $400 \mathrm{ft}$. deep there is huge quantity of natural gas has been reported to governmental agencies. In the Fab.2008 two villagers at Pipariya- Bhutoli have drilled two more tube wells upto the depth of 300-350 feet about $600-700 \mathrm{~m}$ away from the earlier wells in the shales and sandstone rocks of Lower Bhander they could not got the ground water, but there is leakages of natural gas, which is also giving the blue flame.

\section{At NGRI, Hyderabad}

The samples of petroleum gas, soil, water were also collected by the scientists Dr. A.M. Dayal, Dr. Ravi Srivastava, and Dr. D.J.Patil of NGRI Hyderabad along with the author on 4-5 May 2008.The detail geochemical and stable Isotopic studies of the natural petroleum gas, soil and water sample has been done in the Laboratories of NGRI.

\begin{tabular}{|c|c|c|}
\hline Location & Name of Petroleum Gas & Stable Isotopic Value $\boldsymbol{\delta}$ C13 \\
\hline \multirow{2}{*}{ Piparia - Bhutoli } & Methane & -43.6 per mil w.r.t. PDB \\
\cline { 2 - 3 } & Ethane & -24.6 per mil w.r.t. PDB \\
\hline \multirow{2}{*}{ Rahatgarh - Mirkheri } & Methane & -54.9 per mil w.r.t. PDB \\
\cline { 2 - 3 } & Ethane & -26.4 per mil w.r.t. PDB \\
\hline
\end{tabular}

Table 3: Stable Isotopic Value of Hydrocarbon Gas in Sagar District M.P. INDIA [3-6].

The presence of the ethane gas in both the Localities, and $\delta \mathrm{C}^{13}$ value in the range of -.249 per mil.w.r.t.P.D.B. and - 26.4 per mil.w.r.t.P.D.B. indicate the thermogenic source of these gases. On the basis of the geochemical and stable isotopic studies of the natural petroleum gas, soil and water suggest that the samples of the PipariaBhutoli-Rahatgarh-Meerkheri of Sagar District containing $72 \%$ to $99 \%$ of methane, $0.34 \%-0.742 \%$ of Helium, along with the oxygen, carbon dioxide and Nitrogen gases. The stable isotopic $\delta \mathrm{C}^{13}$ value in the range varying from -43.6 per mil. w.r.t PDB for methane 24.66 per mil. w.r.t PDB for ethane at Piparia -Bhutoli to54.9 per mil.w.r.t PDB for methane and per mil. w.r.t PDB for at Rahatgarh are indicative of the THERMOGENIC origin and also that methane Is associated with oil. Bernard [13] suggested a genetic diagram by correlating $\mathrm{C} 1 / \mathrm{C} 2+\mathrm{C} 3$ ) ratio with $\delta \mathrm{C}^{13} 1$ concentration of methane to classify natural gas types. Molecular ratio $\mathrm{C} 1 / \mathrm{C} 2+\mathrm{C} 3$ less than 50 are typical for the thermogenic hydrocarbon gases with $\delta \mathrm{C}^{13}$ values between-30\% and - 55\% (PDB). This suggests that most of the samples fall in the thermogenic range.

The gas result indicate the presence of methane, ethane, propane and butane in Sagar District M.P. The carbon isotope studies suggest that these seeped hydrocarbon are of thermogenic origin and petroliferous in nature and indicate the area is warm for hydrocarbon exploration area.

\section{Conclusion}

In my opinion the natural petroleum and helium gas are containing the higher amount of Methane (72-99\%), and remarkable content $0.34 \%$ to $0.742 \%$ of Helium, and minor amount of oxygen, nitrogen and carbon di oxide, it suggests that it must have been formed at higher temperature condition at deeper horigen in the Pre- 


\section{Petroleum \& Petrochemical Engineering Journal}

Cambrian Vindhyan sedimentary basin( Proterozoic in age). The reservoir must be lying below the ground at least $500 \mathrm{~m}$ or more deep level. The present leakages of natural gas releasing through many hairline cracks/ fracture and feather joints in the sandstone, shales and limestone rocks of the Rewa and Bhander group rocks of the Vindhyan Super Group.

As per the geochemical and stable isotopic studies of Gas samples analysed at NGRI. Find out the methane and ethane gas. The presence of ethane gas collected from the above mentioned localities and the $\delta \mathrm{C}^{13}$ stable isotopic value in the range of -24.9 per mil.w.r.t. per mil to -26.9 per mil w.r.t. PDB. Indicative of the Thermogenic sources.

\section{References}

1. Coleman DD, Meents WF, Liu CL, Keogh RAS (1977) Isotopic identification of leakage gas from underground storage reservoir- a progress report III. Petrology 111: 1-10.

2. Arun Kumar S (2007) Natural Petroleum Gas found in Piparia-Bhutoli- Rahatgarh in Sagar District, Bundelkhand Region, MP. University Journal- Madhya Bharati 53: 122-124.

3. Arun Kumar S (2008a) Discovery of Natural Petroleum gas in the rocks of the Vindhyan Super Group in Sagar District. Bundelkhand Region, MP. Qtrly Jour of GARC 16(1): 24-27.

4. Arun Kumar S (2008b) Fuel Ho-Leakages of Gas in Tube wells spew natural gas. The News Magzine March, pp: 31-32.

5. Arun Kumar S (2008c) Natural Gas leakages from Bore wells in the rocks of the Vindhyan Supergroup in
Sagar and Damoh Districts, MP. Himalayan Geology 29(2): 193.

6. Arun Kumar S (2008d) Natural Gas Reserves in Sagar District. "Srujun" University News Letter, 9: 19.

7. Arun Kumar S (2009a) Gas in the Backyard. In the Business India Magzine, pp: 144.

8. Arun Kumar S (2009b) Thermogenic Petroleum Gas found in tube wells of Sagar District, MP. Madhya Bharati, Diamond Jubilee Volume, pp: 314-319.

9. Arun Kumar S (2009c) The possibility of Petroleum Gas reserve in Southern Bundelkhand Region, MP. University News Letter, Vishwavidyalaya Samvad 2(3).

10. Arun Kumar S, Gajbhiye NS (2010) Discovery of Rare Helium Gas in Sagar District, MP, India. Proc V th Inter Conference, South Valley University Qena, Egypt, pp: 26-30.

11. Prasanna MV, Rasheed MA, Madhavi T, Kalpana G, Patil DJ, et al. (2010) Light gaseous hydrocarbon anomalies in the near surface soils of Sagar District, Vindhyan Basin, India. Current Science 99(11): 15861590.

12. Rajrajan K (1978) Geology of Sagar district and western part of Damoh distt. Memoirs of the Geological Survey of India, GSI, 109.

13. Bernard BB (1978) Light Hydrocarbon in Sediments. Ph.D dissertation, Texas A\&M University, USA, pp: 144. 